\title{
IDEA PODMIOTOWEGO SPRAWSTWA W MORFOLOGII MIAST
}

Zarys treści: Dynamiczny rozwój literatury światowej z zakresu morfologii miast skłania do refleksji nad stanem i kondycją rodzimych badań morfologicznych oraz motywuje do poszerzania spektrum problemów badawczych podejmowanych przez badaczy w Polsce. W związku z powyższym, celem artykułu jest zaprezentowanie nowej na gruncie polskim idei w morfologii miast, jaką jest podmiotowe sprawstwo (agency) oraz zwrócenie uwagi na rolę podmiotów sprawczych (agents of change) jako animatorów/ inicjatorów zmian morfologicznych w przestrzeni miejskiej.

Słowa kluczowe: podmiotowe sprawstwo (agency), podmioty sprawcze (agents), miasto, morfologia miast.

\section{Wprowadzenie}

Ośrodki miejskie, ich położenie, kompozycja oraz elementy składowe, interesowały uczonych i filozofów prawie od początków życia miejskiego. W rezultacie, przez kolejne stulecia, zgromadzono szeroki wachlarz wiedzy opisowej form miejskich w odniesieniu do niemal każdego regionu świata objętego procesem urbanizacji. Jednak dopiero stosunkowo niedawno wykrystalizowało się dążenie do pogłębionego zrozumienia i wyjaśnienia złożoności struktur miejskich i ich ewolucji, co legło u podstaw wyspecjalizowanych gałęzi badań, zorientowanych na rekonstrukcję procesu rozwoju miast. Pojawiły się one w wielu dziedzinach nauk, w tym wiodących, jak chociażby historia, geografia miast, antropologia, socjologia czy architektura. Niemniej należy zauważyć, że zadanie szczegółowej analizy osiedli miejskich pod kątem ich rozplanowania, fizjonomii oraz pochodzenia elementów składowych, całościowo uwzględniające złożoność krajobrazu miejskiego oraz jego przeobrażenia, nie leży u podstaw żadnej $\mathrm{z}$ nich. Zasadniczo bowiem historycy swą uwagę kierują na działania i wytwory ludzkie, rezultatem czego jest opis dziejów (historiografia), geografowie miast analizują układy przestrzenne i ich zróżnicowanie, 
antropolodzy badają rolę kultury w życiu człowieka, socjologowie śledzą funkcjonowanie i zmiany społeczeństwa, architekci zaś dążą do racjonalnego i estetycznego kształtowania przestrzeni oraz form. Jednak kiedy przedstawiciele tych nauk podejmują badania nad układem przestrzennym organizmów miejskich, ich zabudową, krajobrazem oraz genezą składających się na ten organizm części, czynią wkład do morfologii miast, która stanowi jeden z najstarszych kierunków badawczych geografii historycznej, swymi początkami sięgający końca XIX wieku.

\section{Uściślenie pojęć oraz istota podmiotowego sprawstwa w badaniach morfologicznych miast}

Morfologia miasta, czyli nauka o budowie wewnętrznej i zewnętrznej organizmu miejskiego oraz o pochodzeniu (genezie) składających się na ten organizm części wywodzi się z niemieckiej tradycji badań krajobrazowych (Koter 1974). Początków morfologii miast można się dopatrywać w pracach niemieckich geografów, m.in. O. Schlütera (1899), W. Geislera (1924), H. Hassingera (1927), niemniej za prawdziwego twórcę nowocześnie pojmowanej (tj. nieograniczającej się do metod opisowych) morfologii urbanistycznej uważa się M.R.G. Conzena (1907-2000), brytyjskiego geografa niemieckiego pochodzenia, który w Wielkiej Brytanii stworzył największy w świecie ośrodek badań morfologicznych. Conzen, prowadząc liczne badania terenowe, wypracował warsztat metod badawczych morfologii miast, co więcej, wykształcił grupę uczniów, którzy w dalszym ciągu, i to na dużą skalę, rozwijają tę dyscyplinę naukową, przyczyniając się do jej popularyzacji w świecie oraz wyznaczania jej nowych kierunków badawczych (Koter, Kulesza 2007). Pośród nich poważne miejsce zajmuje problematyka podmiotowego sprawstwa (agency), a tym samym analiza roli podmiotów sprawczych (agents ${ }^{1}$ ), w kształtowaniu oraz w przeobrażeniach struktur miejskich. Pojęcia te, stanowiące novum w polskiej morfologii miast, do badań nad strukturą miast i jej przeobrażeniami zapożyczone zostały $\mathrm{z}$ socjologii. W polskojęzycznej literaturze socjologicznej są one jednak różnie tłumaczone albo jako podmiotowość (np. Sztompka 1989; Cichocki 2003), sprawczość (np. Wojciszke 2010), albo jako podmiotowość sprawcza (np. Sewell 2006; Wnuk-Lipiński 2008). Na potrzeby niniejszego opracowania zdecydowano się jednak zastosować propozycję przekładu zaproponowaną przez M. Domecką (2013), a w znaczeniu nadanym przez brytyjską socjolog M.S. Archer (2003, 2013 [2000]), łączącym trzy elementy, ważne z punktu widzenia problematyki przemian morfologicznych miast, mianowicie pierwiastek ludzki, decyzyjny i sprawczy (związany z działaniem). Stąd agents przetłumaczono jako podmioty sprawcze, rozumiane jako ludzi, którzy w dążeniu do realizacji celów

\footnotetext{
${ }^{1} \mathrm{~W}$ języku angielskim stosowane zamiennie z agents of change.
} 
indywidualnych lub zbiorowych podejmują intencjonalne działania przekształcające krajobraz miejski, natomiast agency przetłumaczono jako podmiotowe sprawstwo, rozumiane jako siła motoryczna zmian przestrzennych struktur miejskich, przejawiana $\mathrm{w}$ działaniach jednostek i zbiorowości społecznych. Za Koterem można tym samym stwierdzić, że istotą podmiotowego sprawstwa w badaniach morfologicznych miast jest ,przeniesienie punktu ciężkości analizy z form stworzonych przez człowieka na ludzi, którzy te formy tworzą lub tworzyli” (Koter 2015, s. 138).

Innymi słowy, patrząc przez pryzmat podmiotowego sprawstwa na miasto, można je przedstawić jako scenę, na której kolejni aktorzy, czyli podmioty sprawcze (np. właściciele, architekci, deweloperzy, planiści), odgrywając swoje role, dokonują przekształceń tkanki miejskiej. Analiza działań tych podmiotów, odpowiedzialnych za fizyczne zmiany krajobrazu miejskiego, umożliwia kompleksowe zrozumienie procesów przeobrażeń struktur miejskich, zarówno współczesnych, jak i historycznych (Larkham 1986).

\section{Rozwój idei podmiotowego sprawstwa w literaturze przedmiotu}

Badania podmiotowego sprawstwa $\mathrm{w}$ studiach nad rozwojem przestrzennym miast mają dość długą tradycję. Po raz pierwszy świadomie podjęte zostały na początku lat 70. XX stulecia, m.in. przez H. Cartera (1970), który w pracy poświęconej powstaniu i przeobrażeniach planu walijskiego miasta Llandudno uwagę skierował na rolę decydentów i procesu decyzyjnego jako ważnego czynnika sprawczego w rozwoju przestrzennym miast. Praca Cartera stanowiła jednocześnie ważny postulat podnoszący kwestię potrzeby większej świadomości oraz akcentowania procesów społecznych i ich roli w kształtowaniu otaczającej przestrzeni, jak i w badaniach nad miastami. Odpowiedzią na apel Cartera były liczne prace zorientowane na problem roli podmiotów i czynników sprawczych w kształtowaniu przestrzeni miejskiej. Spośród nich wymienić należy m.in. opracowanie J.W.R. Whitehanda (1977), w którym autor krajobraz miejski ukazał jako owoc czasowego związku pomiędzy procesem innowacji a tempem rozwoju działalności budowlanej oraz zaproponował jego analizę w kontekście koncepcji wyjaśniających dostępność i wartość gruntów, wraz $\mathrm{z}$ badaniem wpływu innowacji na strukturę miast. Whitehand rolę podmiotów sprawczych, jako kreatorów i manipulatorów form miejskich, zwłaszcza w odniesieniu do obszarów centralnych miast, analizował również w swych kolejnych opracowaniach (m.in. Whitehand 1983,1984; Whitehand i Whitehand 1984).

Niemniej dopiero P. Larkham przyczynił się do znacznego rozwoju koncepcji oraz jej rozpowszechnienia w światowych badaniach z zakresu urbomorfologii, głównie za sprawą opracowania The agents of urban change (1986), w którym szczegółowo przeanalizował rolę podmiotów sprawczych w kształtowaniu i przeobrażeniach czterech wybranych obszarów zabudowanych położonych 
w hrabstwie West Midlands, objętych polityką planistyczną i wyznaczonych pod ochronę konserwatorską. Badania Larkhama zapoczątkowały serię opracowań morfologicznych poświęconych podmiotowemu sprawstwu, w pierwszej kolejności analizie wpływu poszczególnych podmiotów na strukturę miast średniowiecznych, m.in. właścicieli ziemskich oraz kościoła (np. Slater 1987; Slater i Rosser 1998; Baker i Holt 2003, Slater 2014), arystokracji (np. Lilley 2001) czy władz miejskich (np. Boogaart 2004). Z kolei dla miast nowożytnych, których struktura przestrzenna odzwierciedla przemiany kulturowe, polityczne i techniczne, będące wyznacznikiem przejścia do nowej epoki, badania podmiotowego sprawstwa objęły m.in. rolę możnowładców w kształtowaniu krajobrazu miejskiego. Przykładem może być praca K.A. Thomasa (2014) poświęcona analizie wpływu absolutystycznych rządów Fryderyka Wilhelma I Hohenzollerna na morfologię i fizjonomię Poczdamu czy opracowanie M. Darin (2014) prezentujące rolę G.E. Haussmanna w przebudowie Paryża. Kolejno, w odniesieniu do miast przemysłowych, wyróżniają się prace zorientowane na rolę właścicieli ziemi w konwersji sposobu jej użytkowania z rolnego na miejski (np. Springett 1982; Hooper 1985; Graham i Proudfoot 1992), a także te poświęcone nowym trendom w planowaniu, np. garden cites czy garden suburbs, będących adaptacją założeń idei miasta-ogrodu na potrzeby przedmieścia (np. Pacione 2014). Dla tego okresu warto również przywołać pracę autorstwa M. Kotera i M. Kuleszy (2014) prezentującą cały wachlarz podmiotów odpowiedzialnych za założenie i rozwój miast przemysłowych w XIX wieku - Łodzi i Żyrardowa. Była to pierwsza praca polskich morfologów miast celowo ukierunkowana na analizę podmiotowego sprawstwa, niemniej opublikowana w anglojęzycznym opracowaniu pt. Shapers of Urban Form, w ograniczonym stopniu dotarła do szerszego grona odbiorców w kraju.

Kolejna seria prac, podkreślająca rolę podmiotów sprawczych w przemianach morfologicznych struktur miejskich, związana jest z rozwojem ruchu modernistycznego, który stanowił jeden $\mathrm{z}$ większych zwrotów w historycznym rozwoju teorii architektury. Dla tego okresu warto wymienić pracę m.in. N. Marzota (2014) poświeconą wpływom architektów włoskich (S. Muratori i G. Caniggia) na struktury miejskie czy opracowanie P.J. Larkhama (2014) prezentujące rolę władz miejskich i planistów w przebudowie miast brytyjskich po drugiej wojnie światowej związanej z wprowadzeniem ustawy o planowaniu przestrzennym z 1947 roku (Town and Country Planning Act of 1947).

Spośród prac ukazujących współczesne przemiany morfologiczne warto natomiast wymienić niezwykle ciekawe studium porównujące działania podmiotów sprawczych $\mathrm{w}$ przebudowie doków dwóch nowozelandzkich miast portowych - Auckland i Wellington, autorstwa K. Gu (2014). W odmiennym kontekście kulturowym osadzona została z kolei praca P.R. Gaubatza (1996) poświęcona wpływowi wielokulturowości na strukturę przestrzenną chińskich miast granicznych, w której przenikają się wpływy chińskie, tybetańskie oraz muzułmańskie. Podobne podejście, traktujące odmienne kultury czy wartości, 
jako potencjalny czynnik modelujący przestrzeń miejską, zaprezentowane zostało w pracy N. Nassera (2003), analizującej przekształcenia krajobrazu miejskiego przez imigrantów. Analogicznie, jako czynnik stymulujący działania podmiotów przekształcające otaczającą przestrzeń miejską, można traktować gospodarkę, zwłaszcza zaś globalizację. W tym nurcie utrzymana została praca Y. Elsheshtawy (2010) ukazująca wpływ przemysłu naftowego, globalizacji i polityki rozwoju na procesy dynamicznej urbanizacji Dubaju.

Analizy podmiotowego sprawstwa w morfologii miast dowodzą uniwersalności idei zarówno pod względem zakresu czasowego, jak i przestrzennego badań. Niemniej, podejmowane dla miast historycznych, wiążą się z ograniczoną ilością danych źródłowych, która często utrudnia wskazanie podmiotów sprawczych, a tym bardziej prześledzenie ich roli w kształtowaniu krajobrazu miejskiego. W związku z tym należy zauważyć, że większość badaczy swą uwagę skupia na okresie od połowy XIX wieku po współczesność, co wiąże się ze zwiększoną dostępnością materiałów źródłowych, w tym kompletnych projektów budowlanych. Informacje w nich zawarte w większości umożliwiają analizę procesów decyzyjnych, prześledzenie roli podmiotów sprawczych (np. architektów i inspektorów budowlanych) oraz uchwycenie różnorodnych czynników, jak np. spekulacja (np. Trowell 1985; Larkham 1988ab; Whitehand 1992, 2001). Warto również podkreślić, że w badaniach podmiotowego sprawstwa ważne miejsce zajmuje analiza roli administracji publicznej oraz właściwych urzędów do spraw polityki przestrzennej i zarządzania krajobrazem w przekształceniach struktur miejskich. Dzieje się tak głównie za sprawą rozbudowanych procedur biurokratycznych, których rezultatem są liczne materiały źródłowe (np. Roger 1981; Larkham 2004, 2014ab).

\section{Grupy rodzajowe podmiotów sprawczych i ich rola w przestrzeni miast}

Idea podmiotowego sprawstwa w ujęciu morfologicznym implikuje patrzenie na miasto, jego położenie i strukturę nie tylko jako na produkt działania sił sprawczych, ale także na proces jego powstawania. Zrozumienie złożoności tego procesu wymaga uznania, że nie występuje tylko jeden rodzaj podmiotów, jak również, że nie występuje tylko jeden rodzaj podmiotowego sprawstwa. To raczej podmiotowe sprawstwo obejmuje zróżnicowane role potencjalnie odgrywane na różnych poziomach decyzyjności. Zróżnicowanie to powstaje wraz ze specjalizacją podmiotów, w swych działaniach opierających się na zasadach i celach względnie komplementarnych, ale również potencjalnie konkurencyjnych. Udział wielu podmiotów w procesie powstawania i przemian struktur miejskich skutkuje wdrażaniem różnych standardów i wzorców. Efekt końcowy formy może zatem nie być zgodny z zamierzeniem lub projektem któregokolwiek $\mathrm{z}$ podmiotów bądź ich grup. Jest najczęściej kompromisem 
wykształconym $\mathrm{w}$ rezultacie ścierania się różnych wizji, niemniej finalnie zaakceptowanym przez ogół.

Oczywiście rola, jaką ludzie odgrywają w kształtowaniu przestrzeni miejskiej, jest zróżnicowana, tak pod względem skali, jak i rodzaju działalności. Mogą oni projektować, budować, ale także burzyć zarówno pojedyncze budynki, jak i znaczne obszary zabudowy. Mogą również inicjować, pobudzać lub kontrolować rozwój zabudowy miejskiej poprzez różne mechanizmy, jak chociażby regulacje planistyczne. Mogą jednocześnie, jako jednostki bądź grupy ludzi, dążyć do ograniczenia skali i tempa realizacji inwestycji. W efekcie podmioty sprawcze, których działania mają realne przełożenie na końcowy obraz formy, tworzą rodzaj łańcucha, tudzież sieć powiązań decydentów, rozpoczynającą się od inicjatora planu, a kończącą się na władzy lokalnej czy społeczności lokalnej (Larkham 1986). Suma działań tych podmiotów w ujęciu chronologicznym, a raczej wypadkowa ścierania się różnych sił, z jednej strony twórczych, których źródłem są podmioty bezpośrednio zaangażowane w proces inwestycyjny, jak inicjator, architekt czy wykonawca, z drugiej strony sił ograniczających, będących efektem działań podmiotów, takich jak właściwe organy do spraw budownictwa, składa się na ostateczny wygląd badanych obiektów. Całościowa analiza ich działań umożliwia szczegółową rekonstrukcję procesu powstawania form miejskich.

Inicjator. Pierwszym ogniwem w sieci podmiotów sprawczych jest inicjator planu, który podejmuje wstępną decyzję rozpoczęcia procesu inwestycyjno-budowlanego. Zwykle jest nim inwestor, który dysponuje jakimś określonym terenem oraz wizją jego zainwestowania. Jego rola w tym procesie jest kluczowa, bowiem nie tylko wprawia w ruch serię zdarzeń prowadzących do fizycznych przeobrażeń struktury zabudowy, ale odgrywa także wiodącą rolę w wyborze firm i innych podmiotów uczestniczących na dalszym etapie przedsięwzięcia (Whitehand 1983, s. 494). Inicjatorem-inwestorem jest najczęściej właściciel nieruchomości, niemniej, zwłaszcza w odniesieniu do drobnych zmian na nieruchomościach handlowych, może być nim również dzierżawca bądź najemca. W odniesieniu do nieruchomości rezydencjonalnych inicjatorem zmian jest niemal wyłącznie właściciel. Należy zauważyć, że w wielu przypadkach inicjator może być jednocześnie deweloperem (Larkham 1986). Zdarza się również, że inicjator zatrudnia kierownika projektu, który pośredniczy w procesie wnioskowania o pozwolenie na budowę oraz nadzoruje proces inwestycyjno-budowlany, stając się jednocześnie kolejnym ogniwem w sieci powiązań decydentów.

Architekt. Inicjator zatrudnia architekta do sporządzenia projektu, który jest wymagany w procesie wnioskowania o pozwolenie na budowę. Wybór architekta jest $\mathrm{z}$ reguły pierwszym, jak również niezwykle ważnym powiązaniem w sieci decyzyjnej danego procesu inwestycyjno-budowlanego. Architekt stara się oczywiście sporządzić projekt, który jak najpełniej oddałby zamysł inicjatora, jednak wzbogaca go również (bądź ogranicza) o rozwiązania „własne”, stosownie do swojej wiedzy, ambicji twórczych oraz wizji. Jak wykazał 
P.J. Larkham (1986), w badaniach podmiotowego sprawstwa w morfologii miast, oprócz samych podmiotów sprawczych i ich roli, szczególnie ważne są również wspomniane powiązania, czyli relacje pomiędzy podmiotami, w pierwszej kolejności między inicjatorem a architektem, a także ich status i proweniencja. Okazuje się bowiem, że dla ostatecznego kształtu obiektu istotne jest to, kim jest inicjator - czy jest to właściciel gruntu (właściciel działki miejskiej), deweloper, duży przedsiębiorca, spółka bądź poważna instytucja, np. bank. Znaczenie ma również to, skąd pochodzi inwestor czy architekt, co często ma przełożenie na skalę i kształt inwestycji. P.J. Larkham (1986) poddał analizie również kwestię wyboru architekta przez inwestora i wykazał, że indywidualni inwestorzy lokalni wybierają zazwyczaj architekta miejscowego lub z pobliskiego większego miasta. Inwestorzy zewnętrzni natomiast oraz więksi deweloperzy i instytucje korzystają z usług dużych, renomowanych biur projektowych. Zdaniem Larkhama o wyborze architekta decyduje także położenie danego ośrodka w stosunku do dużych miast. W tych położonych peryferyjnie najczęściej korzysta się $\mathrm{z}$ architektów lokalnych lub z architektów pochodzących z pobliskich większych miast, natomiast $\mathrm{w}$ tych, które położone są $\mathrm{w}$ pobliżu dużych miast, $\mathrm{w}$ tym Londynu, częściej korzysta się z większych biur projektowych. Kwestia wyboru architekta do realizacji projektu jest niezwykle trudna do uchwycenia, niemniej ważna, ma ona bowiem decydujący wpływ nie tylko na kształt projektu, ale również, bardzo często, na dalszy wybór firm budowlanych, podwykonawców i dostawców.

Wykonawcy projektu. Kolejnym ogniwem w sieci powiązań podmiotów sprawczych są wykonawcy projektu, czyli w pierwszej kolejności kierownik budowy i firmy budowlane. Podobnie jak poprzednicy, również i wykonawcy projektu, w trakcie jego realizacji dokonują często pewnych zmian wynikających np. ze względów technologicznych. Na tym etapie realizacji projektu zaangażowanych jest jeszcze wiele innych podmiotów, np. inspektor nadzoru inwestorskiego, inżynier budowy, kierownik robót czy podwykonawcy. Podmioty te nie są powiązane $\mathrm{w}$ określonej kolejności, a relacje między nimi mogą być bardzo złożone (Larkham 1986).

Użytkownicy. Podmiotowe sprawstwo nie kończy się w momencie realizacji inwestycji. Dalszy etap obejmuje aktywne użytkowanie zrealizowanego projektu, podczas którego potencjalni użytkownicy poddają ocenie jego przydatność i funkcjonalność. Co więcej, aktywne użytkowanie stymuluje dalsze modyfikacje projektu, zgodnie z założeniem K. Kropfa (2014, s. 321), „że nowe rodzaje zachowań wymagają nowych form fizycznych".

Oprócz omówionych, istnieją jeszcze inne podmioty sprawcze, których rola w procesie wdrażania danego projektu inwestycyjnego w życie ma charakter kontrolny i ograniczający. Ich działania często nie stanowią rozmyślnego i zamierzonego elementu projektowania, ale mają za zadanie ukierunkować wysiłki oraz energię inicjatorów i pozostałych podmiotów na właściwy tor, odzwierciedlający lokalny porządek. W tym kontekście należy wymienić m.in. planistę, 
który określa, czy projekt nie koliduje z planem przestrzennego zagospodarowania miasta, inżyniera miejskiego, urzędnika do spraw ochrony środowiska, miejskiego konserwatora zabytków i różnych innych konsultantów (Koter, Kulesza 2007). Szczególną rolę odgrywa również społeczność lokalna, która często nie jest obojętna na zmiany wdrażane w otaczającej ją przestrzeni miejskiej. Ten rodzaj podmiotu, stosując różne mechanizmy nacisku, może z powodzeniem ograniczać, zmieniać bądź nawet powstrzymywać niektóre procesy inwestycyjne, niemal na każdym etapie ich realizacji. Rola społeczności lokalnej jest widoczna zwłaszcza w odniesieniu do tych inwestycji, które silnie oddziałują na wizerunek miasta.

Podsumowując, należy zauważyć, że możliwy jest podział podmiotów sprawczych na podstawie ról, jakie odgrywają w przestrzeni miejskiej. Za K. Kropfem (2014) możemy zatem wskazać tych, którzy inicjują procesy zmian (podmioty inicjujące), tych którzy generują specyfikacje techniczne projektów budowlanych (podmioty generujące), tych którzy nadzorują i ograniczają projekty (podmioty regulujące), tych którzy występują w roli oponentów (podmioty protestujące), tych którzy realizują projekt (podmioty wykonujące) oraz tych, którzy go użytkują (podmioty testujące). Każdy z podmiotów może ogrywać jedną rolę bądź kilka ról jednocześnie.

Warto też zauważyć, że podmiotami sprawczymi odpowiedzialnymi za przeobrażenia krajobrazu miejskiego mogą być nie tylko pojedyncze osoby, ale również grupy ludzi lub organizacje. Niemniej, jak wskazuje K. Kropf, w podmiotowym sprawstwie istotną rolę odgrywa przedstawicielstwo. Tym samym „element publiczny lub społeczny funkcjonujący jako niezorganizowany agregat nie stanowi podmiotu sprawczego" (Kropf 2014, s. 307). Na tym tle, dla analitycznej przejrzystości, podmioty sprawcze można podzielić także z uwagi na interes, któremu służą, m.in. na podmioty indywidualne (działanie w interesie własnym), zbiorowe (działanie w imieniu grupy/organizacji), rządowe (działanie w interesie publicznym).

Lista podmiotów sprawczych odpowiedzialnych za powstawanie i przekształcenia struktur miejskich może być bardzo długa, zwłaszcza w odniesieniu do miast zaliczanych do kategorii tzw. miast historycznych. Dla nich jednak odtworzenie roli poszczególnych podmiotów w zakresie przemian morfologicznych jest najczęściej procesem trudnym i długotrwałym. W wielu przypadkach kompletne dane źródłowe są nie do pozyskania, a badacz może jedynie oprzeć się na wnioskowaniu dedukcyjnym, opartym np. na analizie zachowanych elementów rozplanowania czy budulca. Jeśli uda się jednak odtworzyć proces rozwojowy uwzględniający rolę poszczególnych podmiotów sprawczych w powstawaniu i przekształceniach struktur miejskich, analiza morfologiczna nabiera wymiaru kompleksowego. Badacze podejmujący problematykę podmiotowego sprawstwa w badaniach morfologicznych miast są zgodni, że najpełniejszy obraz roli podmiotów sprawczych w powstawaniu i przeobrażeniach przestrzeni miejskiej 
bądź jej fragmentów można uzyskać poprzez analizę całej sieci powiązań decydentów, niemniej powstają również prace poświęcone jednemu, wybranemu podmiotowi, czego dowodzi omówiony już przegląd literatury badawczej.

\section{Dyskusja i wnioski}

Analiza działań podmiotów sprawczych i ich rezultatów przestrzennych wykracza poza proste, opisowe wyjaśnianie ewolucji i narastania tkanki miejskiej, które często nasuwa myśl o swoistej samoorganizacji struktur urbanistycznych. Wykracza również poza prosty opis architektoniczny, zorientowany głównie na specyfikację techniczną budynku, w którym rola podmiotów jest jedynie sygnalizowana, bez wyraźnej analizy spersonalizowanych danych. Patrzenie na miasto przez pryzmat podmiotowego sprawstwa umożliwia analizę przemian przestrzennych obejmującą nie tylko formę, proces jej powstania i ewolucji, ale także siły sprawcze za nimi stojące. Pozwala tym samym na pełniejsze ujęcie badawcze oraz dogłębne zrozumienie procesów zachodzących $\mathrm{w}$ przestrzeni miast zarówno współcześnie, jak i w retrospektywie historycznej.

Warto przy tym zauważyć, że idea podmiotowego sprawstwa akcentująca zróżnicowane role odgrywane $\mathrm{w}$ przestrzeni miejskiej przez kolejne ogniwa w sieci decydentów, wykazuje silne związki z aktualnymi koncepcjami określającymi rozwój i zmiany struktur miejskich. Mowa przede wszystkim o urban governance, będącej obecnie standardem polityki zarządzania rozwojem miast, uwzględniającej interesy podmiotów indywidualnych, społeczności, instytucji, organizacji, urzędów i in. Podobnie jak w podmiotowym sprawstwie, urban governance wskazuje na szereg interesariuszy, których aktywność może mieć wpływ na zarządzanie miastem, również w wymiarze przestrzennym, stąd przygotowanie strategii rozwoju ośrodka wymaga analizy interesów i opinii poszczególnych podmiotów oraz scenariuszy ich zachowań.

Mając na uwadze powyższe, można śmiało stwierdzić, że problematyka podmiotowego sprawstwa rzuca nowe światło na studia z zakresu urbomorfologii oraz otwiera przed nią nowe pola badawcze. Analiza działań kolejnych podmiotów sprawczych, zwłaszcza jeśli prowadzona w odniesieniu do całej sieci powiązań decydentów odpowiedzialnych za fizyczne zmiany w krajobrazie miast, umożliwia bardziej zintegrowane podejście badawcze. Stanowi dopełnienie klasycznej analizy morfologicznej oraz ważny wkład do bardziej kompleksowych badań. Jednak należy podkreślić, że jest też nie lada wyzwaniem warunkowanym dostępem do materiałów źródłowych. Przypisanie autorstwa znacznej liczbie budynków i ich otoczeniu, które są rezultatem wieloletnich nawarstwień tkanki miejskiej, nie jest bowiem zadaniem łatwym. Nie zawsze możliwe jest pozyskanie kompletnych informacji umożliwiających rekonstrukcję procesu decyzyjnego w odniesieniu do ewolucji tkanki miejskiej, co z pewnością stanowi poważne ograniczenie $\mathrm{w}$ aplikacji idei. Informacje o podmiotach odpowiedzial- 
nych za przeobrażenia form miejskich w czasie mogą być trudno dostępne, niekompletne, zaginione bądź tajne. Nawet jeśli możliwy jest wgląd do projektu budowlanego, może być on mocno uproszczony i przypisany do nazwiska głównego, na owe czasy, architekta miejskiego.

Pozostaje również kwestia możliwości aplikacyjnych idei podmiotowego sprawstwa na gruncie rodzimych badań morfologicznych, zwłaszcza w odniesieniu do czasów odległych. Czy burzliwa przeszłość polityczna naszego kraju oraz spowodowane przez nią poważne straty i ograniczenia w dostępie do materiałów źródłowych, uniemożliwią badania podmiotów sprawczych oraz ich roli w kształtowaniu krajobrazu miast polskich? Odpowiedź na tak postawione pytanie nie może być jednoznaczna, zależy bowiem od podjętej problematyki oraz zakresu czasowego, dla którego miałaby być realizowana. Zasadniczo pogłębione badania roli podmiotów sprawczych na gruncie rodzimym, oparte na materiałach archiwalnych, gromadzonych $\mathrm{w}$ następstwie wdrażania regulacji budowlanych, możliwe są dla okresu od XIX wieku, gdyż właśnie w okresie zaborów kształtowały się podwaliny przyszłego polskiego prawa budowlanego i przepisów budowlanych. W pierwszej kolejności należy mieć jednak na uwadze różnice w zakresie dostępności i jakości materiałów źródłowych dla poszczególnych ziem polskich, będące reperkusją odmiennej polityki państw zaborczych - Prus, Rosji i Austrii.

Poważne braki materiałów archiwalnych występują również w odniesieniu do okresu międzywojennego, zwłaszcza jego pierwszego dziesięciolecia, co spowodowane jest zapewne faktem, że do końca lat 20. XX wieku nadal obowiązywały zaborcze przepisy budowlane. Polskie prawo budowlane wprowadzono w życie dopiero 16.02.1928 roku Rozporządzeniem Prezydenta Rzeczypospolitej, a jego źródłem była Ustawa o prawie budowlanym i zabudowaniu osiedli ${ }^{2}$. Uregulowała ona nie tylko proces budowlany i nadzór nad nim, ale także zagadnienia rozwoju przestrzennego miast i osiedli, m.in. plany zabudowania, kwestie związane z parcelacją terenów budowlanych, scalaniem działek budowlanych czy też przekształceniami działek zabudowanych wadliwie. Po raz pierwszy została określona rola organów państwa w zakresie czuwania nad bezpieczeństwem i porządkiem publicznym w procesie budowlanym. Utworzono również pierwszą strukturę państwowego nadzoru budowlanego, zwaną wówczas „władzą budowlaną", mającą szerokie uprawnienia do wydawania pozwoleń na budowę, pozwoleń na użytkowanie obiektu oraz nakazów i zakazów w obszarze budownictwa (Zwolak 2013, s. 71). Niestety, duża część zgromadzonej wówczas dokumentacji technicznej i budowlanej, jak również korespondencji urzędowej, została bezpowrotnie utracona w następstwie działań wojennych i zmian ustrojowych, niemniej zachowane materiały archiwalne mogą stanowić ważne źródło w badaniach podmiotowego sprawstwa dla omawianego okresu.

\footnotetext{
${ }^{2}$ Dz.U.R.P., 1928, nr 23, poz. 202.
} 
Szczegółowych informacji o podmiotach sprawczych i ich wpływie na krajobraz miast polskich dostarczyć może dokumentacja techniczna i budowlano-architektoniczna z okresu powojennego. Wiąże się to m.in. z zastąpieniem terminu „władzy budowlanej” - „nadzorem budowlanym”, który oprócz czuwania nad projektowaniem i wznoszeniem budynków, sprawowaniem kontroli nad zawodami budowlanymi oraz nad utrzymaniem istniejących budynków w należytym stanie, objął krąg pomiotów uczestniczących w procesie budowlanym, głównie zaś inwestorów państwowych i społecznych, których aktywność decydowała o jakości utrzymywanej, istniejącej i tworzonej substancji budowlanej (Zwolak 2013, s. 74), a nad którymi nadzór budowlany w okresie międzywojennym, z uwagi na pewne niedostatki prawa budowlanego z 1928 roku, był znacznie ograniczony. Kolejne nowelizacje prawa budowlanego w omawianym okresie, nowe ustawy regulujące zagadnienia związane $\mathrm{z}$ procesem inwestycyjno-budowlanym, rozbudowywane organy państwowego nadzoru budowlanego oraz poszerzane kompetencje stosownych urzędów, miały rzecz jasna przełożenie na ilość i szczegółowość wytwarzanej dokumentacji geodezyjnej, kartograficznej, inwestycyjno-budowlanej i in., będącej podstawą badań podmiotowego sprawstwa w morfologii miast. W tym przypadku zachowana dokumentacja również posiada duże luki. Znaczna jej część została bowiem utracona, głównie w trakcie reform administracyjnych Polski i przekazywania jej do urzędów różnych szczebli, często do tego nieprzygotowanych.

\section{Podsumowanie}

Miasta są wytworem historycznej działalności człowieka - niezwykle złożonym produktem rozmyślnego aktu planowania. Jednak na co dzień rola człowieka w kształtowaniu krajobrazu miejskiego jest bardzo często pomijana, stąd powszechny jest również obraz miasta, jako tworu rozrastającego się autonomicznie, bez jasno zidentyfikowanych działań człowieka. Ta dwubiegunowość percepcji otaczającej nas przestrzeni miejskiej rodzi pytanie, kto lub co występuje w roli twórcy, kreatora miast? Pomocna w szukaniu odpowiedzi na nie okazuje się omówiona idea podmiotowego sprawstwa, która akcentując rolę podmiotów sprawczych $\mathrm{w}$ powstawaniu i przeobrażeniach miast, wzbogaca klasyczne ujęcie morfologiczne o analizę spersonalizowanych sił sprawczych. Umożliwia gradację podmiotów sprawczych pod względem skali ich wpływu na przeobrażenia strukturalne miast zarówno w odniesieniu do współczesności, jak i czasów odległych, wskazuje na zmiany podmiotów w różnych okresach historycznych, tak pod względem ich liczby, jak i proweniencji, prezentuje rezultaty ich działalności w przestrzeni miejskiej.

Jednak sukces analiz morfologicznych opartych na badaniach podmiotowego sprawstwa warunkowany jest $\mathrm{w}$ pierwszej kolejności ilością, kompletnością i jakością zachowanych materiałów źródłowych. Naturalnie zatem rezultaty 
badań wpływu podmiotów sprawczych na krajobraz miast historycznych wPolsce nigdy nie dorównają, pod względem szczegółowości i kompleksowości, badaniom tego typu prowadzonym w Europie Zachodniej, zwłaszcza w Wielkiej Brytanii, gdzie ciągłość państwowości nigdy nie została przerwana, a planowanie przestrzenne i nadzór budowlany mają długie i solidne tradycje kształtujące się w następstwie rewolucji przemysłowej, eksplozji demograficznej i urbanistycznej oraz powodowanych nimi problemów socjalnych i bytowych. Niemniej i tak, pomimo wszelkich ograniczeń, badania podmiotowego sprawstwa na gruncie polskiej morfologii urbanistycznej wydają się możliwe, a nawet konieczne bez wątpienia mogą dostarczyć wielu cennych informacji, umożliwiając bardziej wszechstronną analizę struktur miejskich.

\section{LITERATURA}

Archer M.S., 2000, Being human: the problem of agency, Cambridge University Press, Cambridge.

Archer M.S., 2003, Structure, agency and the internal conversation, Cambridge University Press, Cambridge.

Archer M.S., 2013, Człowieczeństwo. Problem sprawstwa, przekł. A. Dziuban, Zakład Wydawniczy NOMOS, Kraków.

Baker N., Holt R., 2003, Urban growth and the medieval Church: Gloucester and Worcester, Ashgate Publishing, Aldershot.

Boogaart T.A., 2004, An ethnogeography of late Medieval Bruges: evolution of the corporate milieu, 1280-1349, Edward Mellen Press, Lampeter, Wales.

Carter H., 1970, A decision-making approach to town plan analysis: a case study of Llandudno, [in:] Carter H. and Davies W.K.D. (eds.), Urban essays: Studies in the geography of Wales, Longman, London, pp. 66-78.

Cichocki R., 2003, Podmiotowość w spoleczeństwie, Wydawnictwo Naukowe Uniwersytetu im. Adama Mickiewicza, Poznań.

Darin M., 2014, Haussmann: Reconsidering his role in the transformation of Paris, [in:] Larkham J.P., Conzen M.P. (eds.), Shapers of urban form. Explorations in morphological agency, Routledge, New York and London, pp. 97-113.

Domecka M., 2013, Wprowadzenie do polskiego tlumaczenia ksiażki Margaret S. Archer: Czlowieczeństwo. Problem sprawstwa, [w:] Mrozowicki A. (red.), Człowieczeństwo. Problem sprawstwa, przekł. A. Dziuban, Zakład Wydawniczy NOMOS, Kraków.

Elsheshtawy Y., 2010, Dubai: Behind an urban spectacle, Routledge, Abingdon.

Gaubatz P.R., 1996, Beyond the Great Wall: Urban form and transformation on the Chinese frontiers, Stanford University Press, Stanford, CA.

Geisler W., 1924, Die deutsche Stadt: ein Beitrag zur Morphologie der Kulturlandschaft, Engelhorn, Stuttgart.

Graham B.J., Proudfoot L., 1992, Landlords, planning, and urban growth in eighteenthand early nineteenth-century Ireland, „Journal of Urban History”, 18, pp. 308-29. 
Gu K., 2014, Morphological processes, planning, and market realities: Reshaping the urban waterfront in Auckland and Wellington, [in:] Larkham J.P., Conzen M.P. (eds.), Shapers of urban form. Explorations in morphological agency, Routledge, New York and London, pp. 267-284.

Hassinger H., 1927, Basel: ein geographisches Städtebild, [w:] Metz F. (red.), Beitrage zur Oberrheinischen Landeskunde, Karlsruher Geographentag, Breslau, s. 103-130.

Hooper A., 1985, The role of landed property in the production of the built environment, Bartlett International Summer School, Paper 6, Bartlett School, University College London, London.

Koter M., 1974, Fizjonomia, morfologia i morfogeneza miasta. Przeglad rozwoju oraz próba uściślenia pojęć, „Zeszyty Naukowe UŁ”, Nauki Matematyczno-Przyrodnicze, seria II, 55, s. 3-16.

Koter M., Kulesza M., 2007, Morfologia miast. Stan i tendencje rozwoju, [w:] Jażdżewska I. (red.), Polska geografia osadnictwa. Dotychczasowy dorobek. Program badań, XX Konwersatorium Wiedzy o Mieście, Łódź, s. 303-314.

Koter M., Kulesza M., 2014, Shaping the housing of industrialists and workers: The textile settlements of Księży Młyn (Łódź) and Żyrardów in Poland, [in:] Larkham J.P., Conzen M.P. (eds.), Shapers of urban form. Explorations in morphological agency, Routledge, New York and London, pp. 152-172.

Koter M., 2015, Morfologia miast - stan i tendencje rozwoju, [w:] Barwiński M. (red.), Geografia historyczna i polityczna w badaniach Marka Kotera - wybór prac, Wydawnictwo Uniwersytetu Łódzkiego, Łódź, s. 133-145.

Kropf K., 2014, Agents and agency, learning, and emergence in the built environment. A theoretical excursion, [in:] Larkham J.P., Conzen M.P. (eds.), Shapers of urban form. Explorations in morphological agency, Routledge, New York and London, pp. 303-322.

Larkham P.J., 1986, The agents of urban change, University of Birmingham.

Larkham P.J., 1988a, Aesthetic control, architectural styles and townscape change, Birmingham.

Larkham P.J., 1988b, Agents and types of change in the conserved townscape, Transactions of the Institute of British Geographers, NS 13, pp. 148-64.

Larkham P.J., 2004, Agents of change in the post-war reconstruction: The interaction of architects, planners, politicians and the public, University of Central England.

Larkham P.J., 2014a, The role of municipal authorities and planners in replanning Britain after Second World War, [in:] Larkham J.P., Conzen M.P. (eds.), Shapers of urban form. Explorations in morphological agency, Routledge, New York and London, pp. 230-250.

Larkham P.J., Conzen M.P., 2014b, Agents, agency, and the urban form: „, The making of the Urban Landscape”, [in:] Larkham J.P., Conzen M.P. (eds.), Shapers of urban form. Explorations in morphological agency, Routledge, New York and London, pp. 3-23.

Lilley K.D., 2001, Urban planning and the design of towns in the Middle Ages: the Earls of Devon and their new towns, „Planning Perspectives”, 16, pp. 1-24.

Marzot N., 2014, Modernism against history: understanding building typology and urban morphology among Italian architects in the twentieth century, [in:] Larkham J.P., Conzen M.P. (eds.), Shapers of urban form. Explorations in morphological agency, Routledge, New York and London, pp. 219-229. 
Nasser N., 2003, The challenge of ethnoscapes, „Urban Morphology”, 7, pp. 45-48.

Pacione M., 2014, Residential differentiations in nineteenth-century Glasgow: morphogenetic study of Pollokshields garden suburb, [in:] Larkham J.P., Conzen M.P. (eds.), Shapers of urban form. Explorations in morphological agency, Routledge, New York and London, pp. 173-192.

Roger R.G., 1981, Sources and methods of urban studies: the contribution of building records, „Area”, 13, pp. 315-321.

Schlüter O., 1899, Bemerkungen zur Siedlungsgeographie, „Geographische Zeitschrift”, 5, s. 65-84.

Sewell W.H. (Jr.), 2006, Teoria struktury: dwoistość, podmiotowość sprawcza a transformacja, [w:] Jasińska-Kania A., Nijakowski L.M., Szacki J., Ziółkowski M. (red.), Wspótczesne teorie socjologiczne, przeł. Anna Zawadzka i Włodzimierz Derczyński, Wydawnictwo Naukowe Scholar, t. 2, Warszawa, s. 700-722.

Slater T.R., 1987, Ideal and reality in English Episcopal medieval town planning, Transactions of the Institute of British Geographers, NS 12, pp. 191-203.

Slater T.R., 2014, Ecclesiastical authorities and the form of medieval towns, [in:] Larkham J.P., Conzen M.P. (eds.), Shapers of urban form. Explorations in morphological agency, Routledge, New York and London, pp. 46-62.

Slater T.R., Rosser G., 1998, The Church in medieval town, Ashgate, Aldershot.

Springett J., 1982, Landowners and urban development: the Ramsden Estate and nineteenth-century Huddersfield, „Journal of Historical Geography”, 8, pp. 129-44.

Sztompka P., 1989, Socjologiczna teoria podmiotowości, [w:] Buczkowski P., Cichocki R. (red.), Podmiotowość: możliwość, rzeczywistość, konieczność, Wydawnictwo Nakom, Poznań, s. 11-13.

Trowell F., 1985, Speculative housing development in Leeds and the involvement of local architects in the design process, 1866-1914, „Construction History”, 1, pp. 13-24.

Thomas K.A., 2014, Absolute decisions: Towns fit for a king, [in:] Larkham J.P., Conzen M.P. (eds.), Shapers of urban form. Explorations in morphological agency, Routledge, New York and London, pp. 83-96.

Whitehand J.W.R., 1977, The basis for an historic-geographical theory of urban form, Transactions of the Institute of British Geographers, NS 2, pp. 400-416.

Whitehand J.W.R., 1983, Land-use structure, built form and agents of change, Institute of British Geographers Special Publication, 1, pp. 41-59.

Whitehand J.W.R., 1984, Rebuilding town centres: Developers, architects and styles, Occasional Publication, 19, Department of Geography, University of Birmingham, Birmingham.

Whitehand J.W.R., 1992, The makers of British towns: architects, builders and property owners, c. 1850-1939, „Journal of Historical Geography”, 18, pp. 417-438.

Whitehand J.W.R., 2001, The creators of England's inter-war suburbs, „Urban History”, 28, pp. 218-234.

Whitehand J.W.R., Whitehand S.M., 1984, The physical fabric of town centres: the agents of change, Transactions of the Institute of British Geographers, NS 9, pp. 231-247.

Wnuk-Lipiński E., 2008, Socjologia życia publicznego, Wydawnictwo Naukowe Scholar, Warszawa. 
Wojciszke B., 2010, Sprawczość i wspólnotowość. Podstawowe wymiary spostrzegania społecznego, Gdańskie Wydawnictwo Psychologiczne, Gdańsk.

Zwolak S., 2013, Ewolucja instytucji nadzoru budowlanego w Polsce, [w:] Sagan S. (red.), „Ius et Administratio”, 4, s. 66-85.

\title{
THE IDEA OF AGENCY IN URBAN MORPHOLOGY
}

\begin{abstract}
The dynamic development of the urban morphology in the world encourages reflection on the state and condition of the indigenous morphological studies and provokes to broadening the spectrum of research problems undertaken by Polish morphologists. Therefore, the aim of the article is to present new idea in urban morphology, namely the idea of agency and to draw attention to the role of agents of change, as animators/initiators of morphological changes in urban space.

The concept of agency, borrowed from sociology to the studies on the structure of cities and its transformations, presents the city as a stage on which subsequent actors/ decision makers (owners, architects, developers, planners and others), by playing their roles, transform the urban fabric. Analysis of their activities enables comprehensive understanding of the processes of transformation of urban structures, both in contemporary and historical context. It goes beyond simple descriptive analysis of their evolution and the growth that often suggest the specific self-regulation of urban structures. It also goes well beyond a simple architectural description, which indicates agency only indirectly, through the presentation of the complex nature of urban structures, but often without a clear analysis of personalized information about agents of change.

The researches on agency in the urban morphology, successfully undertaken since the 80 s of last century, mainly on the grounds of the British school of morphology, currently experience a strong interest in the global studies on cities. They allow the gradation of agents of change in terms of their impact on the structural transformations of cities (and their fragments), both in relation to the present and past; they indicate changes of agents of change in different historical periods, both in terms of their number and provenance; they present the results of their activities in urban space.
\end{abstract}

Key words: agency, agents of change, city, urban morphology.

Dr Magdalena Deptuła Katedra Geografii Politycznej i Studiów Regionalnych Wydział Nauk Geograficznych Uniwersytet Łódzki 